\title{
ANALYSIS OF THE RELATIONSHIP BETWEEN THE STAGE OF ECONOMIC DEVELOPMENT AND THE STATE OF CLUSTER DEVELOPMENT ${ }^{1}$
}

Starting from the fact that clusters contribute to the competitiveness of industry sectors and the high standard of living in regions where clusters operate, the aim of this paper is to show the relationship between the stage of economic development and the state of cluster development at the level of national economies. Using the ANOVA statistical method the authors have accepted the hypothesis that the state of cluster development in national economies varies depending on the stage of economic development. In order to evaluate the state of cluster development in the country and the stage of economic development, the authors used the secondary data from the World Economic Forum (WEF), published in "The Global Competitiveness Report 2013-2014”. Although the stage of economic development is influenced by many economic and political factors, the authors assume that the stage of economic development predominantly depends on the decision and willingness of political and business leaders to lead the country to higher stages of economic development and sustainable economic growth. Their decision has an impact on cluster development in the country, and therefore influences the possibility of clusters to improve economic development and national competitiveness, especially in emerging markets and developing economies.

Keywords: clusters, competitiveness, economic development

JEL Classifications: R11, O12

DOI: $10.15611 /$ aoe.2017.2.12

\section{INTRODUCTION}

Although national competitiveness and the stage of economic development are influenced by many economic and political factors (according to the WEF national competitiveness depends on more than 100 variables), the authors assume that the stage of economic development predominantly depends on the decision and willingness of political and business leaders in the country to lead the national economy to a higher stage of economic

\footnotetext{
${ }^{*}$ Institute of Agricultural Economics, Belgrade, Serbia.

${ }^{* *}$ Institute of Economic Sciences, Belgrade, Serbia.

**** Belgrade Banking Academy, Belgrade, Serbia.

${ }^{1}$ This paper is a part of research projects III46006, III47009 and OI179015 financed by the Ministry of Science and Technological Development of the Republic of Serbia.
} 
development, higher rates of economic growth and sustainable and strong national competitiveness.

The development of well-functioning clusters is one of the essential steps in a country's moving to an advanced economy and higher national competitiveness (Porter, 2008). To allow a location to become more productive, develop local capacity, improve products and processes and, ultimately, to innovate, a cluster must build up over time (ibid.). Many authors and institutions indicate clusters as important and strong engines for driving the country's economic growth (GDP) and competitiveness as a tool for improving regional development, innovations, investments, and particularly competition and competitiveness of small and medium enterprises (SMEs) (Porter, 1989, 2008; Enright, 2003; Paraušić et al, 2014; EC, 2006a, 2008; Europe INNOVA, 2008; England's Regional Development Agencies, 2003; World Bank, 2009; OECD, 2010).

In China for example, the numerous special economic zones (SEZs) and industrial clusters that have sprung up since the reforms are undoubtedly two important engines for driving the country's growth and they have made crucial contributions to China's economic success (Zeng, 2011). Some clusters have begun to grow out of certain SEZs and the emergence of these clusters actually hinges on the success of these SEZs, which serve as their "greenhouse", and on market forces over time (ibid.). However, SEZs and clusters in China have some specific challenges like diminishing the preferential policies and privileged status, the lack of conspicuous sector or product differentiation (for SEZs), the fragmentation and lack of horizontal linkages, and the lack of skilled technical and managerial personal in clusters (ibid.). Also, it can indicate that industrial clusters, due to their lower wage rates than SEZs, perform better in increasing FDI growth and GDP growth (regardless of the benefits firms in SEZs get from government), while SEZs allow companies to pay higher wages and better help to improve the growth of social welfare factors (Udenwa, 2013).

The authors emphasize that clusters significantly differ between advanced economies and emerging markets and developing economies (the division of the countries in these two groups is based on the IMF World Economic Outlook Database, April 2014). Conditions for cluster development are far better in advanced economies than in emerging markets and developing economies, so the second group of countries have undeveloped clusters, while advanced economies are characterized by the presence of numerous and strong clusters ("world class cluster") in many industry segments. Also, barriers to improve cluster competitiveness may certainly vary across 
countries depending on the stage of development they are in. Thus clusters in the middle-income countries require additionally sophisticated interventions in segments of economic policy, supply chain, corporate strategies, etc. On the other hand for the clusters in lower-income countries, efforts on competitiveness may have to start with the correction of market and government failures, and with reform in basic institutional structures, etc. (The World Bank, 2009).

The differences in clusters in the two analyzed groups of countries are present in organizational networks, extent, depth and width of the cluster, critical mass, productivity improvement and business competitiveness, etc. The most important differences are described below (Porter, 1989, 2008; Sölvell et al. 2003; Ketels et al. 2006; Ketels and Sölvell, 2006; EC, 2006b; WEF, 2008; OECD, 2010):

- In advanced economies national and regional competitiveness is achieved with a range of clusters based on the high share of knowledge and innovation. These countries have developed clusters; they have density, width and depth. In addition, there is a dense network of relations and connections between the cluster members and specialized infrastructure which emerges from public and private investments, and numerous institutions provide specialized education, training, information, research and technical support to the SMEs sector. Silicon Valley (California) and Bangalore (India) are well known computer software clusters, Wall Street (New York), The City (London) and Zurich are strong financial services clusters. Many of these clusters started without an explicit cluster policy, albeit public sector actions have nevertheless played an important role in aspects of their development.

- Countries that belong to the group of emerging markets and developing economies have declarative intercession for cluster development. However there is a lack of developed clusters and no favourable macroeconomic, institutional, infrastructural and business environment and policy for their development. In these countries, clusters have the following characteristics: (1) local character and intensive utilization of natural resources and low-skilled labour; (2) clusters tend to be shallow and to rely primarily on foreign components, services, and technology; (3) the relatively competitive companies tend to operate more on their own rather than as cluster participants (communication is limited and links between existing firms and institutions are not well developed); (4) clusters take the form of hierarchical, hub-and-spoke networks surrounding a few large companies, government entities or distributors; 
(5) Cluster formation is impeded by low local education and skill levels, weaknesses in technology, the lack of access to capital and poorly developed institutions; (6) Government policy may also work against cluster formation; restrictions on industrial location and subsidies artificially spread out companies; protected from competition, companies engage in monopolistic behaviour that further retards cluster development; (7) university and technical school curricula, centrally dictated, fail to adapt to cluster needs.

With the above mentioned in mind, by using the ANOVA statistical method, the authors will test hypothesis that the state of cluster development in national economies varies depending on the stage of economic development, on a sample of 148 countries, covered by the WEF's report The Global Competitiveness Report 2013-2014 (WEF, 2013).

Furthermore, the authors analyzed the state and challenges of cluster development in several countries in a group of emerging markets and developing economies and point out the conditions of successful cluster development in that group of countries.

\section{THEORETICAL FRAMEWORK}

Stages of economic development. In theory, stages of economic development are associated with sources of national competitiveness and the wealth or poverty of the countries (Cho, Moon, 1998; United Nations, 2002; WEF, 2013). Theories of competitiveness and economic development have changed and evolved over time when identifying the reasons why some countries are rich and others are poor (Dragutinović, et al., 2005; Mervar, 2003; Porter, 1990, 2008; Salvatore, 1998; Krugman, Obstfeld, 2009). In response to the question of which production factors contribute most to the economic prosperity of a country and its international competitiveness, scientists have started from the natural resources and the importance of availability of production factors (capital accumulation enables the specialization and division of labour and contributes to higher productivity). They have come to the importance of technological progress as an endogenous variable (a variable that depends on company and government investment in human capital, that is in education and skills), the importance of innovation and knowledge (accumulated human capital of high expertise and specialization), their spreading through externalities (which are most visible in clusters), as well as the importance of a proactive, dynamic and challenging business environment in which companies are born and 
compete. While the theory of comparative advantage (the traditional view of competition) directs the countries to compete on the basis of plentiful availability of the basic factors of production (natural resources, labour and capital) and the high efficiency of their use (an advantage based on low costs or price structure of production and high labour productivity), theories of competitive advantage which are complementary with the theory of the comparative advantage ( $\mathrm{H}-\mathrm{O}$ theory), consider the international competitiveness of countries based on "new" and sophisticated factors, such as: economies of scale, product differentiation (mass production of branded products within monopolistic competition), changes in consumer preferences, the presence of clusters and innovative and stimulant local business environment, intense local competition, specialized knowledge and skills, developed science and technological infrastructure etc.

Clusters. Numerous authors recognize innovation-driven clusters as factors that contribute to the creation of sustainable international competitiveness of enterprises, regions and national economies (Porter, 1990, 1989, 2008; Rosenfeld, 2002; Sölvell et al. 2003; Enright 2003) and institutions (UNIDO, 2001; EC, 2006a; 2006b; 2008; OECD, 2006, 2007, 2010; US Council on Competitiveness, 2007; World Bank, 2009; Europa InterCluster, 2010).

The predecessors of cluster theory can be tracked to the time of the British economist Alfred Marshall (1890), who was the first to use the terms "thickly peopled industrial district" and "stimulant industrial atmosphere". This economist signalled the tendency of enterprises to be located near their key suppliers, buyers and competitors and points out the causes and advantages of the concentration of industries in particular localities. The term "industrial districts" that appeared in the 1970s, amidst the global recession when clusters began to associate with dynamic industrial growth in some regions, is accredited to the Italian author Becattini $(1989,2002)$. During the 1980s and 1990s, the theories of regional development recognized the so-called models of territorial approach to innovations that are appending innovation diffusion, as an important drive of economic development, to the factors for the development of the region (Terluin, 2001). According to these theories, the paradox of regional development in the era of globalization is resolved either by business concentration into regional clusters or by the aggregation of local companies into multinational businesses.

Full affirmation of the cluster concept in modern literature was given by Professor Porter, on whose interpretation of clusters rely almost all authors 
and institutions at the beginning of this century. The specificity of Porter's interpretation of the sources of national competitiveness (Porter, 1990) is reflected in the importance and significance that the author sets for the quality of business environment and clusters as an integral part of the business environment, in relation to the creation of national competitiveness, as well as the international competitiveness of companies in specific industries or industry segments. According to Porter (1990), globally competitive and export-oriented companies do not succeed in isolation but in clusters of industries, which include strong horizontal (common customers, technology, channels) and vertical links (customers/suppliers) among companies and institutions. Porter (1989, p. 78) defines clusters as "geographic concentrations of interconnected companies and institutions in a particular field" or "critical masses in one place, of unusual competitive success in particular fields". In addition, Porter (2008, pp. 213-214) defines clusters as "geographic concentration of interconnected companies, specialized suppliers, service providers, firms in related industries, and associated institutions (for example, universities, standards agencies, and trade associations) in a particular field that compete but also cooperate".

Basic terms associated with clusters are (Porter, 1989, 2008; Enright, 2003; Europe INNOVA, 2008; England's Regional Development Agencies, 2003; World Bank, 2009; OECD, 2010):

- Cluster with location specific externalities and synergies produce a range of benefits for companies: higher competitiveness, more efficient access to infrastructure, specialized suppliers, human resources, and inputs, including capital, reduction of costs, access to information and services, better recognition and marketing, etc.

- Cluster characteristics such as specialised suppliers, research comercialisation, established public-private partnerships (especially cooperation between universities and industries in R\&D), critical mass of human capital, skills enhancement, etc. are important factors for a cluster's growth and success.

- Clusters have density (this refers to the number of companies and institutions in the cluster which are geographical concentrations in a specific geographic area and economic sector), width (established horizontal connections with companies that produce/provide complementary products/services or have a similar market position) and depth (vertical connections of members in the cluster or links of the companies in the value chain from input purchase, to sale). 
- Cooperation between the cluster members (companies) is achieved through intensive co-operation, but also through competitive relation (high competitive intensity).

- Clusters are characterized by a certain dynamic social and organizational element, the so-called "social glue" or social capital (intense formal and informal contacts) that holds the different interlinked actors together and provide knowledge spillovers.

Clusters differ fundamentally from industrial policy, value chains, and SEZs (World Bank, 2009). However it is worth noting that in developing economies SEZs and industrial parks act as prominent policy levers favouring cluster growth, and they can better foster economic upgrading if they have a cluster rather than a general focus (Porter, 2008). Through grassroots activities in SEZs, which take into account regional specificities as well as historical and socio-economic conditions, they may become the support instrument for the development of clusters at regional level (Oleksiuk, 2017).

It is also important to emphasize that in developing countries and transition ones clusters are usually developed through cluster initiatives defined as organized efforts to increase growth and the competitiveness of clusters within a region through the joint activities of companies, governments and scientific research institutions or with a person, organisation or consortium leading the actions (Sölvell et al. 2003; EC, 2008; OECD, 2010). In practical work, cluster initiatives are often identified with clusters (empirical or market phenomenon of grouping the companies and institutions as a result of entrepreneurial spirit and action of market forces).

\section{DATA SOURCES AND RESEARCH METHODOLOGY}

We investigate the effect of the stage of economic development on the state of cluster development. As our dependent variable (development of clusters) is continuous and our independent variable (economic development) is categorical, we will use the one-way analysis of variance (ANOVA). ANOVA is a special case of the general linear model, so the relationship between the dependent variable (the level of development of clusters) and the non-metric impact factor (economic development) is formulated by the statistical linear model.

The impact of the stage of economic development on the state of cluster development in national economies is tested with the following hypothesis: 
$\boldsymbol{H}_{\boldsymbol{o}}$ : There is no effect of the stage of economic development on the state of cluster development on a national level.

$\boldsymbol{H}_{1}$ : The state of cluster development in national economies varies depending on the stage of economic development.

To test the working hypothesis, the authors used the following data published in The Global Competitiveness Report 2013-2014 (WEF, 2013):

(1) Country's stage of economic development and

(2) State of cluster development.

Stage of economic development is a controlled factor whose effect on the variability of the clusters is examined. The WEF distinguishes three stages of economic development, expressed in GDP and export structure of national economy (Table 1). Moreover, these stages represent sources of the national competitive advantage which the country is using. According to Table 1 and based on grouping countries at each stage of development by the WEF (WEF, 2013, p. 11), the authors distinguish the following models:

- Model A (factor-driven economies) includes 58 countries in stage 1 of development and countries in transition from stage 1 to stage 2, with GDP per capita less than USD 2,999. In this model, countries compete on the basis of their factor endowments (primarily low-skilled labour and natural resources). Companies depend on imported components, machinery and technology, and compete on the basis of price and sell basic products or commodities with their low productivity reflected in low wages.

- Model B (efficiency-driven economies) includes 53 countries in stage 2 of development and countries in transition from stage 2 to 3, with GDP per capita from USD 3,000 to USD 17,000. In this model, countries develop more efficient production processes and increase product quality (wages have risen).

- Model C (innovation-driven economies) includes 37 countries in stage 3of development, with GDP per capita more than USD 17,000. In this model, countries are able to sustain higher wages and the associated standard of living only if their businesses are able to compete with new and/or unique products, services, models and processes.

State of cluster development is a phenomenon whose variability is being examined. This variable is one of more than 100 variables of competitiveness included by the WEF in the highly comprehensive Global Competitiveness Index (GCI). All the competitiveness variables the WEF uses for GCI calculation are grouped in twelve competitiveness pillars and three sub-indexes of competitiveness, while the variable State of cluster 
Table 1

Income thresholds for country's stage of development

\begin{tabular}{|c|c|c|c|c|c|}
\hline \multirow{2}{*}{$\begin{array}{c}\text { Stages } \\
\text { of development }\end{array}$} & \multicolumn{2}{|c|}{$\begin{array}{c}\text { Model A } \\
\text { Factor-driven } \\
\text { economies }\end{array}$} & \multicolumn{2}{|c|}{$\begin{array}{c}\text { Model B } \\
\text { Efficiency-driven } \\
\text { economies }\end{array}$} & \multirow{2}{*}{\begin{tabular}{|c|}
$\begin{array}{c}\text { Model C } \\
\text { Innovation- } \\
\text { driven } \\
\text { economies }\end{array}$ \\
Stage 3 \\
\end{tabular}} \\
\hline & Stage 1 & $\begin{array}{c}\text { Transition } \\
\text { from stage } \\
1 \text { to } 2 \\
\end{array}$ & Stage 2 & $\begin{array}{c}\text { Transition } \\
\text { from stage } \\
2 \text { to } 3 \\
\end{array}$ & \\
\hline $\begin{array}{l}\text { GDP per capita } \\
\text { (US\$) thresholds } 1\end{array}$ & $<2,000$ & $2,000-2,999$ & $3,000-8,999$ & $9,000-17,000$ & $>17,000$ \\
\hline
\end{tabular}

Note: ${ }^{1}$ Two criteria are used to allocate countries into stages of development: (1) level of GDP per capita at market exchange rates, and (2) share of exports of mineral goods in total exports of goods and services. The second criterion is used to adjust for countries that are wealthy, but where prosperity is based on the extraction of resources. The WEF assumes that countries exporting more than 70 percent of mineral products (measured using a five-year average) are to a large extent factor-driven. Hence for economies with a high dependency on mineral resources, GDP per capita is not the sole criterion for the determination of the stage of development.

Source: The Global Competitiveness Report 2013-2014, WEF 2013, p. 10.

development is a constitutive part of the eleventh competitiveness pillar Business sophistication and belongs to the third competitiveness sub-index Innovation and sophistication factors (WEF, 2013, p. 51). The state of cluster development is determined by different indicators such as the number of clusters in the economy, the existence of a critical mass of participants, recognition on the market, the existence of depth and wideness of clusters, externalities, the positive impact of cluster on innovation, productivity and competitiveness of the companies and regions involved in the cluster, etc.

Using the parametric statistical method ANOVA for comparing the group means the influence of the controlled factor (Stage of economic development) on the variability of the observed phenomena (State of cluster development) is examined. According to Stage of economic development, three groups of countries are isolated, and due to the unequal number of countries in the sample, the following Tukey-Kramer method for unequal sample sizes (Lowry, 1999-2000) is used to test if there is a significant difference in respect to the development of clusters among them:

$$
\bar{y}_{i \bullet}-\bar{y}_{j \bullet} \pm \frac{q_{\alpha ; r ; N-r}}{\sqrt{2}} \hat{\sigma}_{\varepsilon} \sqrt{\frac{1}{n_{i}}+\frac{1}{n_{j}}}
$$

where $n_{i}$ and $n_{j}$ are the sizes of groups $i$ and $j$, respectively. 
For the application of the selected statistical method, the following assumptions are met (Graph 1):

- errors are independent and normally distributed,

- homogeneity of variances of the population, and

- outliers are not significant.

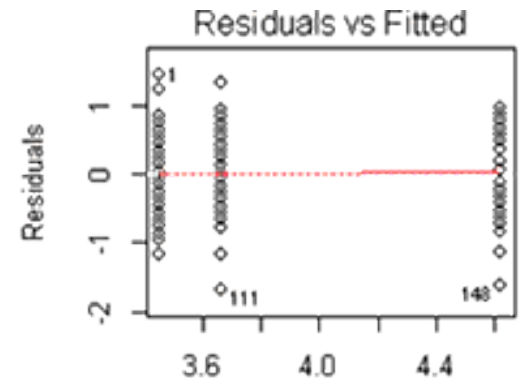

Fitted values

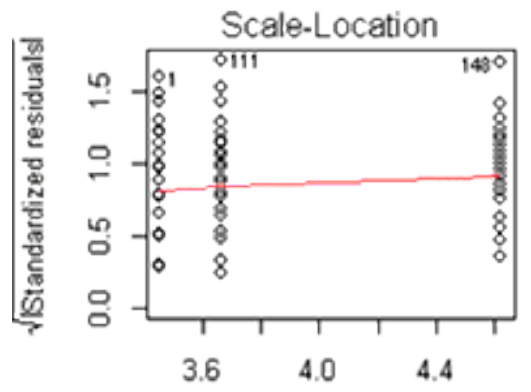

Fitted values

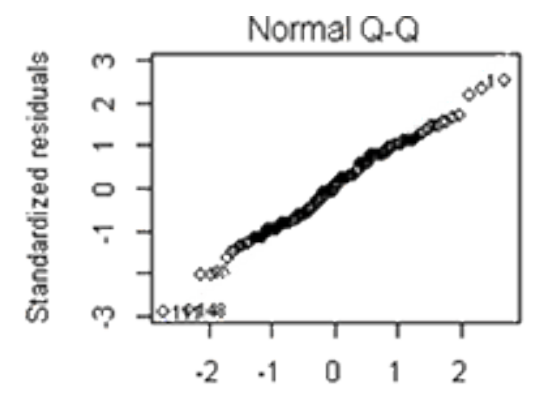

Theoretical Quantiles

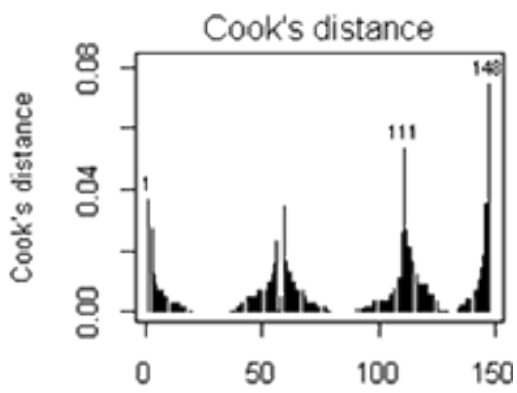

Obs. number

Graph 1. Testing requirements for the application of ANOVA

Source: R statistical output.

Apart from the already mentioned statistical test for the study of this type of relationship, we could also use Spearman's rank correlation coefficient which is based on the ranked data, bearing in mind the following facts:

- Stage of economic development is determined by the achieved GDP per capita. The IMF data base (World Economic Outlook Database, April 2014) provides data of GDP per capita for all countries in the world, which creates 
the opportunity for the authors to rank the analyzed countries (148 countries included in the WEF report) according to GDP per capita.

- World Economic Forum (WEF) provides the ranking of 148 countries according to estimated cluster development (WEF, 2013, p. 526).

This statistical method could confirm the working hypothesis that there is a high positive correlation between the two variables: State of cluster development and Stage of economic development. However, since the World Economic Forum provides groups of countries according to the stages of economic development and criteria for grouping (Table 1) and considering that we have all the prerequisites for the application of ANOVA, the authors consider that ANOVA as a parametric statistical method better shows the influence of the controlled variable (Stage of economic development) and its modalities (A: Factor driven economies, B: Efficiency driven economies and C: Innovation driven economies) to the State of cluster development.

\section{RESULTS AND DISCUSSION}

The controlled factor which is supposed to systematically affect the variability of the observed phenomenon State of cluster development is Stage of economic development (categorical data). The total number of countries in the sample is 148 , and the fact that together they produce about $98 \%$ of world GDP, stands for the unbiasedness of the sample. The working hypothesis is tested using the ANOVA statistical method, and the results are presented in Table 2 .

The results point out the acceptance of $\mathrm{H}_{1}$ that state of cluster development in national economies varies depending on the stage of economic development (given the $p$ value). This was demonstrated by the relatively large difference between the arithmetic means of samples $\left(M S_{A}\right)$. Other uncontrollable factors that also affect the variability of the observed phenomenon caused variations within individual groups or small deviations between the groups $\left(M S_{R}\right)$ which are significantly less than the variation between groups.

As the working hypothesis is accepted at the significance level of 0.05 , groups of countries between which there is a marked difference in the arithmetic means and variance in respect to the development of clusters are examined. The answer to this question is given by the Tukey-Kramer method for unequal sample sizes, at the significance level of 0.05 and $95 \%$ Tukey-Kramer confidence intervals (Table 3). 
Table 2

Results of the ANOVA application in testing $H_{1}$

\begin{tabular}{l|c|c|c|c|c}
\hline \multicolumn{1}{c|}{ Source of variation } & Df & $\begin{array}{c}\text { Sum } \\
\text { of squares } \\
(\boldsymbol{S S})\end{array}$ & $\begin{array}{c}\text { Mean square } \\
(\boldsymbol{M S})\end{array}$ & $\boldsymbol{F}$ value & $\boldsymbol{P}$ \\
\hline Between groups & 2 & $S S_{A}=33.02$ & $M S_{A}=16.508$ & 49.56 & $<0.001^{*}$ \\
\hline Residuals (within groups) & 145 & $S S_{R}=48.29$ & $M S_{R}=0.333$ & & \\
\hline Total & 147 & 81.31 & & & \\
\hline
\end{tabular}

Conclusion:

$H_{o}$ is rejected at the significance level of 0.05

At the significance level of 0.05 , the hypothesis $H_{1}$ is accepted, according to which the state of cluster development in national economies varies depending on the stage of economic development.

Summary of groups (factor levels)

\begin{tabular}{l|c|c|c|c}
\hline \multicolumn{1}{c|}{ Groups (levels) } & Mean & Variance & $\begin{array}{c}\text { Standard } \\
\text { deviation }\end{array}$ & Group size \\
\hline Group 1. Factor driven economies & 3.45 & 0.30 & 0.54 & 58 \\
\cline { 2 - 5 } Group 2. Efficiency driven economies & 3.66 & 0.33 & 0.57 & 53 \\
\cline { 2 - 5 } Group 3. Innovation driven economies & 4.62 & 0.40 & 0.63 & 37 \\
\hline
\end{tabular}

Note: ${ }^{*}$ high level of significance

Source: R statistical output.

Table 3

The Tukey-Kramer method for unequal sample sizes

\begin{tabular}{c|c|c|c|c|c}
\hline Groups & Difference & Lower & Upper & $\boldsymbol{p}$-value & Decision \\
\hline $1-2$ & -0.211 & -0.470 & 0.049 & 0.136 & Fail to reject $H_{0}$ \\
\hline $1-3$ & -1.171 & -1.458 & -0.883 & 0 & Reject $H_{0}$ \\
\hline $2-3$ & -0.960 & -1.253 & -0.667 & 0 & Reject $H_{0}$ \\
\hline
\end{tabular}

Source: R statistical output.

The application of the Tukey-Kramer method for unequal sample sizes indicates that there are significant differences between the first and the third group of countries, as well as among the second and the third group (Table 3 ). This means that the development of clusters is considerably different:

- between the factor-driven and innovation-driven economies, and

- between the efficiency-driven and innovation-driven economies.

Research can be improved by introducing additional variables into the analysis. In this way, one of the next steps which the authors intend to make 
is to involve in the analysis two other controlled factors and their modalities in order to check their impact of the variable State of cluster development, such as:

- Achieved technological development of a country. One of the ways of defining the modality of the above mentioned factor could be the following: A - High technology countries, B - Countries with the mean degree of technological development, $\mathrm{C}$ - Low technology countries. To define modality for this factor the estimation of the 9th pillar of the GCI (Technological readiness) could be used along with the subjective estimation by the authors on setting limits stipulated between the modalities (see The Global Competitiveness Report 2013-2014, WEF, 2013, pp. 20, 21, 50).

- Innovativeness of national economy. The way to define the modality of the above mentioned factor could be as follows: A - countries with high potential for innovation, B - countries with lower potential for innovation, $\mathrm{C}-$ countries with low innovation potential. Similar to the previously described case, these modalities could be determined bearing in mind the estimation of the 12th pillar of the GCI (R\&D Innovation, see The Global Competitiveness Report 2013-2014, WEF, 2013, pp. 22, 51).

\section{CONSTRAINTS ON THE RESEARCH}

The most important constraint in the study and collection of primary data on clusters development was the lack of a central registry for worldwide clusters which would provide quantitative (number of clusters), and particularly qualitative data on the degree of development of clusters (their competitive strength, depth, wideness, intensity of connections between members, etc.).

Data on clusters (number of clusters, their strength and other qualitative characteristics) are provided by the online platform called European Cluster Observatory (ECO), that maps clusters based on regions and sectors (the ECO used combination of geographical and industrial dimensions for maps clusters). However, the ECO provides data for 36 European countries only (in 404 European regions), and the greatest limitation of this platform is the fact that clusters are identified on the basis of statistical data on employment (European Commission, 2008). It is important to emphasize that high employment in a particular sector of the industry does not imply the existence of clusters, and this is an especially inadequate basis for the mapping of clusters in Central and Eastern Europe, which have high 
employment in the primary sector, but are without the elements of cluster networking. In addition to this limitation, the ECO does not provide sufficient qualitative data for the analysis of the factors that generate cluster competitiveness (no data reflecting the quality of connections in a cluster, cluster innovation, overflow of knowledge between different actors, etc.).

The WEF provides information on the state of cluster development at national level in a number of countries. However, significant limitation of this source is the fact that the assessment of development of clusters is subjective. In fact, some indicators of competitiveness used by the WEF in calculating the GCI are the so-called hard data which are provided by international organizations and national and international statistical sources. However, the evaluation of the large number of competitiveness indicators that enter into the GCI calculation, including State of cluster development, the WEF provides on the basis of the annual Executive Opinion Survey, in other words based on the subjective reviews of managers from surveyed companies.

In survey by the WEF in 2013 a total of 13,638 surveys were received (WEF, 2013, p. 83), representing an average of 94.7 respondents per country. Through the Executive Opinion Survey, the respondents rate the individual variables of competitiveness on a scale of 1 to 7 , where one end of the scale $($ score $=1)$ represents the worst possible situation, while the other end (grade=7) represents the best possible situation. For example, the variable State of cluster development was examined by the WEF with the following question (WEF, 2013, p. 526): "In your country, how widespread are well-developed and deep clusters (geographic concentrations of firms, suppliers, producers of related products and services, and specialized institutions in a particular field)? [1=nonexistent; 7=widespread in many fields]. The WEF uses an arithmetic mean to aggregate individual variables within a category.

\section{CLUSTERS IN SELECTED EMERGING MARKETS AND DEVELOPING ECONOMIES AND ASSUMPTIONS OF CLUSTER DEVELOPMENT}

As we proved that the state of cluster development in national economies varies depending on stages of economic development, hereinafter the authors analyze the state and challenges of cluster development in selected emerging markets and developing economies, in order to draw attention to some common characteristics in cluster development, as well as to the necessary directions and assumptions of future cluster's activities. 
The classification of countries in the group of "emerging markets and developing economies" is based on the IMF database (IMF World Economic Outlook, 2014, April) and it corresponds to a large extent with Table 1 (countries in three stages of economic development). Thus the group of emerging markets and developing economies include factor driven and efficiency driven economies.

It should be noted that the country classification in the IMF World Economic Outlook divides the world into two major groups: advanced economies, and emerging market and developing economies, and that the classification of countries based on their share in aggregate GDP (GDP shares are based on the purchasing-power-parity valuation of these economies' GDP), exports of goods and services, and the population. Emerging market and developing economies are also classified according to analytical criteria that reflect the composition of export earnings (main sources of export earnings) and other income from abroad; net external position (the distinction between net creditor and net debtor economies), and for the net debtors, financial criteria based on external financing sources and experience with external debt servicing (IMF, 2013).

\subsection{State and challenges of cluster development in selected countries in a group of emerging markets and developing economies}

Most of the countries in the group of emerging markets and developing economies have a lower GDP per capita (GDP based on purchasing-powerparity) than advanced economies (IMF, April 2014) and in today's increasingly knowledge-intensive and globalized economy their companies are still not able to compete by producing new, different and unique products using sophisticated production processes and technologies, so the main sources of a country's export earnings differ from advanced economies.

The existing literature shows that clusters in many of these countries are not well developed, cluster policy is inefficient, and the biggest stumbling block to their development is the absence of favourable macroeconomic, institutional, infrastructural and business environment. Therefore the cluster programmes often result in meaningless activities or become the means of subsidizing politically connected companies or industries. Clusters face serious challenges and constraints such as: weak linkages (poor cooperation) among agents (between firms within the cluster and within the same industry in long production chain), weak links between businesses and knowledge institution (low levels of $\mathrm{R} \& \mathrm{D}$ ), weak governmental and institutional 
support, labour market rigidity, difficulties in achieving a critical mass of firms and critical mass of skills and talent, failure to meet international standards, insufficient supplier depth, etc. (Fairbanks and Lindsay, 1997; Porter, 1989, 2008; Sölvell at al. 2003; Ketels at al., 2006; Ketels and Sölvell, 2006; EC, 2006b; WEF, 2008; Gálvez-Nogales, 2010; Zeng, 2008; Gwenhamo, 2011).

Below are some examples showing the stage and challenges of cluster development in African countries, and in Poland, Hungary, Croatia, and Serbia. These countries belong to emerging markets and developing economies (IMF classification), and also they are in the group of Factor driven economies and economies in transition to a higher stage of development (model A) and Efficiency driven economies and economies in transition to a higher stage of development (model B, Table 1).

Model A. In this group of economies belong mostly African countries (WEF, 2013, p. 11). Having a low GDP per capita, these countries prove that traditional sources of competitiveness (factor advantages, like unskilled labour, low cost of local labour, natural resources), in terms of market globalization, liberalization and high mobility of all production factors, lead to the further preservation of poverty and depletion of natural resources (Porter, 1986, 2008; Fairbanks and Lindsay, 1997, World Bank, 2006). While exports in these countries can grow for a time based on low cost local labour or natural resources exploited with imported technology, such an approach is ultimately limited.

Clusters contribute significantly to Africa's economic growth and through them enterprises are able to overcome constraints in capital, skills, technology and markets. They provide jobs for the continent's growing population, thus enabling families not only to survive, but also to educate their children and perhaps move out of poverty. However clusters face serious challenges in the areas of technology, natural resources, infrastructure, skill acquisition, and quality control and basic prerequisites for the their development (such as macro-economic, political and legal stability) are still not met. The major challenges of the analyzed clusters are: low productivity; weak firm capacity; lack of capital, especially long-term financing and financial constraints for small producers, lack of effective dissemination of $R \& D$ results to firms; weak linkages with knowledge institutions and lack of technological support; lack of innovation both in product and process; inadequate physical infrastructure; weak public institutions; enhanced international competition; lack of effective marketing/branding strategy and expertise; vulnerability to foreign exchange 
and import duties; resource depletion and environmental pollution, etc. (Zeng, 2008). These factors, especially underdeveloped public institutions and macroeconomic stability, are not just obstacles for cluster development but also present barriers for attracting foreign direct investment in these countries (Gwenhamo, 2011).

South Africa is one of the most advanced countries in Africa with a developed mining cluster, automotive cluster and wines cluster. The government has helped the automotive cluster adjust to international competition through the support of the Motor Industry Development Program (MIDP), but the MIDP has come to an end and clusters must address weaknesses in regard to labour market rigidity and unrest, lack of skilled technicians, low levels of R\&D, and insufficient supplier depth (Alfaro et al. 2012).

Model B. In this group the authors analyze the stage and challenges of cluster development in Serbia (group of efficiency-driven economies), and in three economies Poland, Hungary and Croatia, which are in transition from efficiency-driven to innovation-driven economies (WEF, 2013, p. 11).

Serbia (in cluster development ranked 129 out of 148 countries, WEF, 2013 , p. 526). Cluster initiatives are established with the primary objective to apply for public funds for cluster support and they are missing the least common denominator in terms of defining the future interest that gathers cluster members (Mijačić, 2011). In business practice, companies in clusters are inactive, there are no executed cluster projects, clusters are weak in terms of production, human and financial resources, participation of cluster members (particularly scientific research institutions) is at a low level, without established trust or cooperation among them (Paraušić, 2012).

The Institute for Territorial Economic Development (InTER) conducted an analysis of the results of the programme of support for cluster development in Serbia for the period 2007-2015 (Žarković et al. 2016). The results indicated that the programme helped to promote the idea of association in clusters among SMEs and also the successful development of several clusters, especially in the sector of information and communication technologies. However, there is still not enough understanding of the cluster concept and benefits of that type of association of SMEs. The programme was not able to contribute to a higher level of the productivity, competitiveness and innovation of the clusters and SMEs in clusters and also there is still no impact on increasing the membership in the clusters and the strengthening of relations between cluster members (ibid.).

Poland (in cluster development ranked 104 out of 148 countries, WEF, 2013, p. 526). Despite the fact that there are not many clusters in Poland, 
their significance is ever-increasing (Bylok et al. 2016). The majority of cluster initiatives is relatively young (created between 2007-2009), they function both in sectors recognized as innovative as well as more traditional, but the commonest clusters are in the ICT sector (Clusters in Poland, 2012). Membership of clusters is a source of interest mainly for micro-scale and small enterprises who perceive the possibility of achieving substantial benefits through them (Bylok et al. 2016, p. 176).

The role of SEZs is very important in cluster development. In the recent period they have created, established, developed, participated or supported many clusters, and some of SEZs are also members of the clusters. For example, the Kamienna Góra SEZ for Medium Business established the Educational Cluster (which was the first cluster of this type within an SEZ), the Legnica SEZ has created three clusters (automotive, educational and aviation), the Katowice SEZ is one of the initiators of the automotive cluster (Silesia Automotive Platform), the Łódź SEZ was one of the initiators of the Łódź Education Cluster and also a member of the ICT Central Poland Cluster, the aircraft companies located in the Mielec SEZ are members of the Aviation Valley, the most effectively developing cluster in Poland which has Key National Cluster status, etc. (Special Economic Zones in Poland, 2016).

In the sector of agriculture and rural development, the efforts and initiatives in establishing new links between the farmers, community and other components of the agriculture sector such as the processing plants, companies supplying farm inputs and marketing agricultural products, are still very inefficient (Bronisz and Heijman, 2008, p. 39). Cluster initiatives acting in different fields of agri-food sector operations or resource related with this sector and rural areas are not strongly oriented on the agri-food sector and the identified types of clusters connected with this sector. This could be caused by insufficient cooperation and the low degree of integration of farmers and food processing companies, among other factors (Figiel et al. 2014, p. 225).

Generally, clusters in Poland are burdened with a multitude of problems that hinder their development (Bylok, 2016, pp. 176, 179) such as: the lack of knowledge associated with the potential benefits for the economy and the particular entities; the lack of thorough knowledge relating to the management of clusters; the lack of a large enterprise in a strong position which could become the driving force of its development in the market, especially because SMEs have limited possibilities of investing financial resources in the search for new technological solutions or the creation of a new product; there is no policy of supporting clusters (despite the instruments 
prepared to initiate cluster initiatives), etc., the level of Polish cluster internationalization operations is also relatively low and the most popular mode of internationalization is export (Jankowska, Główka, 2016).

The main aim of future cluster policy (2014-2020) should concentrate on supporting the innovativeness and competitiveness of the Polish economy based on: (a) the intensification of cooperation, interaction and flow of knowledge within the clusters, and (b) supporting the development of strategic economic specializations or key clusters (Polish Agency for Enterprise Development, 2012). Also the attempts of the Polish government should be directed to push the internationalization of micro, small and medium-sized enterprises via cluster initiatives on the one hand, and on the other hand to develop some kind of incentives for large companies to participate in cluster organizations as in reality exports are dominated by large firms (Jankowska, Główka, 2016).

Hungary (in cluster development ranked 111 out of 148 countries, WEF, 2013, p. 526). The authors (Szanyi et al. 2010) have found ample evidence of the existence of activity concentrations in branches and regions that have strong FIEs (foreign investments enterprises) influence, such as the automotive and ICT sectors (the development of these sectors by far exceeded previous levels). To some extent the Hungarian cluster development policy has been inspired by the French approach with targeted support to clusters through the development of an accreditation system. Although there are over 120 cluster initiatives, at this stage significant support is targeted towards 25 clusters in a narrow range of sectors. There is a dedicated agency responsible for cluster policy and also a highly structured system of support which focuses resources upon a target group of accredited clusters whilst also providing lower levels of support to emerging cluster initiatives. An important point to note is that cluster development policy has yet not proven to be a panacea for economic development disparities in Hungary and it is clear that clusters have performed better in Hungary in regions of existing economic strength (EU Best Practice in Cluster Development Policies, 2012).

Croatia (in cluster development ranked 114 out of 148 countries, WEF, 2013, p. 526). Croatia has developed a national cluster development strategy, but regional cluster development strategies are missing. A number of clusters have been developed around Croatia on the specific initiative of Regional Development Agencies. Examples include: the ACH (Automotive Cluster of Croatia) cluster and ICT cluster started by Istria Development Agency, the Međimurje I.T. Cluster (MIT) created by REDEA (the Regional 
Development Agency of Međimurje County), and Klaster Slavonska Jabuka (Slavonian Apple Cluster) created by the Regional Development Agency of Slavonia and Baranja etc. amongst others. There is therefore some evidence of top-down cluster development being undertaken at a county level by Regional Development Agencies in Croatia (EU Best Practice in Cluster Development Policies, 2012).

The crucial problem of clusters development in Croatia is regional and national non-coordination, according to cluster policies and their governance. Dynamic bottom-up and interactive process between policy makers and practitioners in Croatia does not exist. Some regional development agencies have made some initiatives on clusters but, although some institutions know why clusters are important, there is no co-operation, coordination and no synergy between the actors, nor mutual trust between them (Dragičević, Obadić, 2014).

\subsection{Assumptions of cluster development}

Developed institutions and infrastructure for the emerging clusters, combined with the proper location and business (market and entrepreneurship) represent a crucial condition for the growth and development of clusters in any country. While the existence of these assumptions is implicit in the advanced economies, in emerging markets and developing economies this condition is still insufficiently developed and represents a significant limitation to the growth and development of the SME sector and cluster development.

Considering clusters' contribution to economic development and competitiveness, as well as the fact that conditions for cluster development are far better in advanced economies than in emerging markets and developing economies, the authors analyze conditions and assumptions for cluster development in the emerging markets and developing economies which are in the competence of political and business leaders.

These assumptions are listed below and based on previous analysis and the literature review (Porter, 2000, 2008; Rosenfeld, 2002; Enright 2003; England's Regional Development Agencies, 2003; EC, 2006b; 2007, 2008; Brenner, Mühlig, 2007; Europe Innova, 2008; Zeng, 2008; Ketels 2009; World Bank, 2009; 2012; Business Europe, 2009; OECD, 2010; Paraušić, 2012; Polish Agency for Enterprise Development, 2012; Žarković, et al. 2016):

- Political competencies and political environment. Cluster initiatives in emerging markets and developing economies require sustained efforts to develop a common platform between the private and public sectors to 
systematically formulate problems, undertake diagnostics and analyses and design reforms on both micro and macro fronts. Financial support from the government institutions will not be crucial, but rather actions that the state has been taking to remove limitations of SMEs development, which are located in macroeconomic policy and the microeconomic business environment. In creating a simulative business environment, the role of the state will be crucial in developing and implementing the following conditions: (1) an institutional framework for the SMEs sector (effective legislative and judicial framework, effective law implementation, protection of property rights and intellectual property rights); (2) physical, scientific and innovation infrastructure; (3) incentives for investment, innovation and employment; (4) efficient financial market; (5) effective competition policy; (6) depolarization of public institutions and transparency of government policy. Also, government measures have to include efforts to: strengthen and upgrade skill training; encourage further knowledge acquisition, adaptation, and dissemination; strengthen educational and technology institutes and their links with the business sector (institutes and universities should be encouraged to become more attuned to industry needs), establish and enforce clear regulations, standards, and quality assurance mechanisms.

- Competence of business leaders. Below are given the most important conditions in the field of internal cluster capacities which are in the competence of business leaders: (1) solving the issue of cluster activities and projects financing (through membership fees or by charging services that clusters provide, it is impossible to finance the cluster; thus the survival and functioning of the existing clusters will depend on the possibility of project financing of clusters); (2) increase the critical mass of clusters and their development in the regions and sectors where countries have regional recognition, specificity and tradition of production, high concentration of producers/processors and a high level of knowledge and experience of all market participants; (3) active cooperation of cluster members (with the companies in the product value chain and with related companies) based on trust, long-term relationships, business ethics, and reached consensus on common objectives and cluster development strategy; (4) developed entrepreneurial initiatives of business entities in order to increase association, networking and implementation of joint projects and activities; (5) developed competitive spirit of cluster members; (6) increase the production, export and the innovation cluster capacities.

All the requirements necessary for cluster development in emerging markets and developing economies are also the requirements to create a sustainable 
competitive advantage of the SMEs sector, requirements to increase exports, employment and in general to achieve sustainable economic growth and higher stages of economic development. It is important to emphasize that none of these requirements alone can influence cluster development and sustainability, but taken together creating synergy, they make a favourable and stimulating environment for the development of clusters.

At the same time it is important to emphasize that clusters have to be built according to the specific economic and social characteristics in each country and each country should create its own cluster policy according to its situation concerning the development of clusters and its specific needs (Dragičević, Obadić, 2014).

\section{CONCLUSION}

The development of well-functioning clusters is one of the essential steps in moving to an advanced economy, higher national competitiveness, and successful economic development. Cluster policy is a key pillar of regional policy with a significant potential for regional competitiveness. Sectors with strong and developed clusters have achieved high growth in production, exports, international competitiveness, innovation and visibility in the global economy. Clusters enable the development of highly sophisticated and specialized production factors (highly skilled, educated and qualified manpower, innovative technology, modern equipment, developed scientific and information basis, social capital), that cannot be easily imitated by distant competitors (even with the high mobility of all production factors) and in that way they can contribute to the creation of sustainable national competitive advantages and the higher stages of economic development. Thus, it is very important for emerging markets and developing economies to identify ways and sources for cluster development.

Using the statistical method of ANOVA, the authors have confirmed the hypothesis that the state of cluster development in national economies varies depending on the stage of economic development, at the significance level of 0.05 .

Advanced economies are characterized by the presence of competitiveness and innovative clusters in many areas of the economy. Clusters in these countries are recognized in the domestic and foreign markets, have a critical mass of participants, high export activity and significantly contribute to increasing the productivity and competitiveness of the participating members and regions in which they operate. On the contrary, in emerging markets and 
developing economies, clusters are underdeveloped: there are a small number of clusters and companies involved in clusters, the clusters are not operational, the networks among the members are not sufficiently developed, they are often unrecognizable in the region in which they operate, as well as at the national and international markets, they lack many supporting industries and institutions for successful development.

Considering contribution of clusters to competitiveness and economic development of countries, as well as the fact that conditions for cluster development are far better in advanced economies than in emerging markets and developing economies, the authors analyzed the assumptions for cluster development within the competence of political and business leaders in some of the emerging markets and developing economies. Assumptions for cluster development within the competence of political leaders and institutions refer to the actions that have been taken to remove the limitations of SMEs development which are located in macroeconomic policy and microeconomic business environment. By meeting these assumptions, political leaders also create the conditions for higher stages of economic development and higher rates of economic growth. Assumptions for cluster development within the competence of business leaders refer to the strengthening of internal cluster capacities, such as: solving the issue of cluster financing, increasing the critical mass of clusters and the cooperation of cluster members, development of entrepreneurial initiatives and competitive spirit of cluster members; increasing the production, export and innovation cluster capacities.

In further research the authors intend to analyze whether the achieved technological readiness and innovation capacity of countries have an impact on the state of cluster development at a national level.

\section{REFERENCES}

Alfaro, A. L., Bizuneh, G., Moore, R., Ueno, S., Wang, R., South Africa: Automotive Cluster. Harvard Business School, 2012.

Becattini, G., Sectors and/or Districts: Some Remarks on the Conceptual Foundations of Industrial Economics [in:] Goodman, E., Bamford, J. (eds.) Small Firms and Industrial Districts in Italy, pp. 123-135. London: Routledge, London, 1989 (translation of the original 1979 work).

Becattini, G., Industrial Sectors and Industrial Districts: Tools for Industrial Analysis, "European Planning Studies", Vol. 10, No 4, 2002, pp. 483-493, 2002.

Brenner, T., Mühlig, A., Factors and Mechanisms Causing the Emergence of Local Industrial Clusters, "Papers on Economic and Evolution", \#0723, Evolutionary Economics Group, Max Planck Institute of Economics, Jena, 2007. 
Bronisz, U., Heijman, W., Competitiveness of Polish Regional Agro-clusters. Applied Studies in Agribusiness and Commerce, pp. 35-40, Agroinform Publishing House, Budapest, 2008.

Business Clusters: Promoting Enterprise in Central and Eastern Europe, LEED Programme, OECD, 2006.

Business Europe, European Clusters for Recovery, Brussels, 2009.

Bylok, F., Pabian, A., Kuceba, R., Management of a Cluster as a Network for Cooperation between SMEs in Poland, "Small Enterprise Research", Vol. 23, No. 2, pp. 172-181, 2016.

Cho, D., Moon, H. C., A nation's International Competitiveness in Different Stages of Economic Development, “Advances in Competitiveness Research”, Reprint, Vol. 6, No. 1, pp. 5-19, 1998.

Cluster policies. Innovation Policy Platform, OECD, 2010.

Clusters in Poland, Catalogue, Polish Agency For Enterprise Development, Warsaw 2012.

Competitive Regional Clusters: National Policy Approaches. Policy Brief, OECD, 2007.

Dragutinovic, D., Filipovic, M., Cvetanovic, S., Theory of Economic Growth and Development, Center for publishing, Faculty of Economics, Belgrade, 2005.

Dragičevic, M., Obadic, A., Cluster Policy and Cluster Governance in Croatia. The 7th International Conference for Entrepreneurship, Innovation and Regional Development (ICEIRD), Nicosia, Cyprus, June, 2014.

Dzierżanowski, M. (ed.) Directions and Assumptions of Polish Cluster Policy until 2020: Recommendations of the Working Group for Cluster Policy. Polish Agency for Enterprise Development, Warsaw, 2012.

ECO/European Cluster Observatory, www.clusterobservatory.eu. Accessed on May 15, 2013.

England's Regional Development Agencies, A Practical Guide to Cluster Development, 2003.

Enright, M., Regional Clusters: What We Know and What We Should Know [in:] Bröcker, J., Dohse, D., Soltwedel, R. (eds.), Innovation Clusters and Interregional Competition, pp.99-129. Springer-Verlag, Berlin, 2003.

European Commission. Putting Knowledge into Practice: A Broad-based Innovation Strategy for the EU. Commission of the European Communities, Brussels, $\operatorname{COM}(2006) 502$, 2006a.

European Commission. Innobarometer on Cluster's Role in Facilitating Innovation in Europe. Flash Eurobarometer No 187, The Gallup Organization, 2006b.

European Commission. The European Cluster Memorandum: Promoting European Innovation through Clusters, An Agenda for Policy Action. Europe INNOVA initiative, 2007.

European Commission. The Concept of Clusters and Cluster Policies and Their Role for Competitiveness and Innovation: Main Statistical Results and Lessons Learned. Commission Staff Working Document SEC 2637, 2008.

Europe Innova. Cluster policy in Europe: a brief summary of cluster policies in 31 European countries, 2008.

Europa InterCluster. The Emerging of European World Class Clusters. White Paper, Brussels, July 2010. 
EU Best Practice in Cluster Development Policies. Prepared for the Ministry of Economy, Labour and Entrepreneurship (MELE) and the Central Finance and Contracting Agency (CFCA), Government of the Republic of Croatia. Maxwell Stamp, January 2012.

Fairbanks, M., Lindsay S., Plowing the Sea: Nurturing the Hidden Sources of Growth in the Developing World. Harvard Business School Press, Boston, 1997.

Figiel, S., Kuberska, D., Kufel, J., Agri-food Clusters in Poland, Institute of Agricultural and Food Economics, National Research Institute, Warsaw, No 135.1, 2014.

Gálvez-Nogales, E., Agro-based Clusters in Developing Countries: Staying Competitive in a Globalized Economy. FAO, Rome, 2010.

Gwenhamo, F., Foreign Direct Investment in Zimbabwe: The Role of Institutional and Macroeconomic Factors, "South African Journal of Economics", Vol. 79, Issue 3, pp. 211-223, 2011.

IMF/International Monetary Fund, World Economic Outlook Database, www.imf.org/ external/pubs/ft/weo/2014/01/weodata/index.aspx, April 2014.

IMF/International Monetary Fund. World Economic Outlook, Statistical Appendix, www.imf.org/external/pubs/ft/weo/2016/02/weodata/groups.htm, April 2013.

Jankowska, B., Główka, C., Clusters on the Road to Internationalization - Evidence from a CEE Economy, “Competitiveness Review”, Vol. 26, Issue 4, pp. 395-414, 2016.

Ketels, C., Sölvell, Ö., Innovation Clusters in the 10 New Member States of the EU. Luxembourg, Office for Official Publications of the European Communities, 2006.

Ketels, C., Lindqvist, G., Sölvell, Ö., Cluster Initiatives in Developing and Transition Economies. Center for Strategy and Competitiveness, Stockholm, 2006.

Ketels, C., Clusters, Cluster Policy and Swedish Competitiveness in the Global Economy. Expert report No. 30 to Sweden's Globalisation Council, Stockholm, 2009.

Krugman, P. R., Obstfeld, M., International Economics: Theory and Policy. Pearson International Edition, 2009.

Lowry, R. (1999-2000). One-Way Analysis of Variance for Independent Samples, Vassar College, USA. http://faculty.vassar.edu/lowry/PDF/c14p1.pdf. Accessed on January 22, 2013.

Marshall, A. (1890). Principles of Economics. Rod Hay's Archive for History of Economic Thought. http://www.marxists.org/reference/subject/economics/marshall. Accessed on May 20, 2013.

Mervar, A., An Essay on Recent Contributions to the Theory of Economic Growth, "Economic Review", Vol. 54, No 3-4, Croatian Society of Economists, Economic Institute Zagreb, 2003.

Mijačić, D., State Analysis of Business Infrastructure in the Republic of Serbia, National Agency for Regional Development, Belgrade, 2011.

Oleksiuk, A., Cluster Policy and Development of the Polish Special Economic Zones, "International Journal of Social Science and Economic Research", Vol. 02, Issue 02, 2017.

Parausic, V., Clusters in Serbian Agribusiness Sector, Ph.D. thesis, unpublished material. Faculty of Business Studies, Megatrend University, Belgrade, 2012. 
Parausic, V., Cvijanovic, D., Mihailovic, B., Veljkovic, K., Correlation between the State of Cluster Development and National Competitiveness in the Global Competitiveness Report of the World Economic Forum 2012-2013, “Economic Research”, Vol. 27, No 1, 2014.

Porter, M. E., Competition in Global Industries. Harvard Business School Press, Boston, Massachusetts, 1986.

Porter, M. E., The Competitive Advantage of Nations. The Free Press, New York,1990.

Porter, M. E., Clusters and the New Economics of Competition, "Harvard Business Review", pp. 77-90, November-December 1998.

Porter, M. E., Location, Competition and Economic Development: Local Clusters in a Global Economy, "Economic Development Quarterly", Vol. 14, Issue 1, pp. 15-34, 2000.

Porter, M. E., On Competition, "Harvard Business Review Book”, 2008.

Rosenfeld, S. A., Creating Smart Systems, A Guide to Cluster Strategies in Less Favoured Regions. Carrboro, North Carolina, April 2002.

Salvatore, D., International Economics, $6^{\text {th }}$ edition. Prentice Hall, 1998.

Szanyi, M., Iwasaki, I., Csizmadia, P., Illéssy, M., Makó, C., Emergence and Development of Industry Clusters in Hungary, Searching for a Critical Mass of Business via Cluster Mapping. IER Discussion Paper Series A, No. 539, Institute of Economic Research, Hitotsubashi University, Kunitachi, Tokyo, May 2010.

Sölvell, Ö., Lindqvist, G., Ketels, C., The Cluster Initiative Green Book. Bromma Tryck AB, Stockholm, 2003.

Special Economic Zones in Poland. Colliers International, 2016. www.colliers.com/en-p1//media/files/emea/poland/reports/2016/Colliers_Report_Special_Economic_Zones_Poland_ EN.pdf, 2016.

Terluin, I., Rural Regions in the EU: Exploring Differences in Economic Development. Dissertaties-Rijksuniversiteit Groningen, 2001.

The Comprehensive R Archive Network, http://cran.r-project.org/

Udenwa, N., A Comparative Performance Analysis between Special Economic Zones and Industrial Clusters in China. Morgan State University, Document Preview, December 2013. http://search.proquest.com/docview/1556499386, 2013.

UNIDO, Development of Clusters and Networks of SMEs. United Nations Industrial Development Organisation, Vienna, 2001

United Nations. The Relationship between Competition, Competitiveness and Development. United Nations Conference on Trade and Development, 2002.

US Council on Competitiveness. Innovation America - Cluster-Based Strategies for Growing State Economies. The National Governors Association's Innovation America, 2007.

World Bank, Where is the Wealth of Nations, Measuring Capital for the 21st Century?, 2006

World Bank, Clusters for Competitiveness: A Practical Guide and Policy Implications for Developing Cluster Initiatives. International Trade Department, 2009.

World Bank, Agricultural Innovation Systems An Investment Sourcebook. The World Bank, Washington, 2012.

WEF/World Economic Forum. The Global Competitiveness Report 2008-2009. Ed. K. Schwab. Geneva, 2008. 
WEF/World Economic Forum. The Global Competitiveness Report 2013-2014. Ed. K. Schwab. Geneva, 2013

Zeng, D. Z. (ed.), Knowledge, Technology and Cluster-Based Growth in Africa. The International Bank for Reconstruction and Development/World Bank, 2008.

Zeng, D. Z., How Do Special Economic Zones and Industrial Clusters Drive China's Rapid Development? Policy Research Working Paper, No. 5583. The World Bank, March 2011.

Zarkovic, J, Mijacic, D, Sovrlic, T., Clusters Ten Years Later: Analysis of the Effects of the Cluster Development Support Program in Serbia 2007-2015. Institute for Territorial Economic Development (InTER), Belgrade, 2016.

Received: June 2014, revised: March 2017 